\title{
Calvijn en de Dordtse Leerregels ${ }^{1}$
}

\author{
W.H. Velema \\ Theologische Universiteit \\ Apeldoorn \\ NEDERLAND
}

\begin{abstract}
In this article a surprising similarity in structure between Calvin's teachings on predestination and those of the Canons of Dordt is indicated. Christ is, namely, central in both. One has to read both Calvin and the Canons of Dordt within their own line of argument. Following this point of departure, one cannot speak of a philosophical system or structure, which would bypass Christ. In fact, the practical nature of the texts strikes the reader indeed. In conclusion a number of practical conclusions are drawn by the author.
\end{abstract}

\section{Luther, Bucer en Calvijn}

In dit artikel geven we eerst aandacht aan Calvijns leer van de uitverkiezing. ${ }^{2}$ Wij zetten voorop dat de verkiezing bij Calvijn een wezenlijk punt is, zoals Van 't Spijker (1976:85-111) in aansluiting bij Niesel (1957:161-184) ${ }^{3}$ en Wendel (1968:232-250) het typeert. Hij voegt eraan toe dat ook voor Bucer de praedestinatie of electie de prima causa nostrae salutis is, en derhalve de primus locus theologiae, met een verwijzing naar Bucers commentaar op de brief aan de Efeziërs (Van 't Spijker, 1976:87). De uitdrukking primus locus lijkt mij nog ka-

Dit artikel bevat de hoofdinhoud van een lezing dic ik op 23 Juli 1992 over bogenoemd onderwerp in Blocmfonten heb gehouden Bepaalde passages, voofal dic welke verband houden met Graaflands interpretatic van Calvijn, zijn weggelaten. Hetzelfde geldt van oen aantal citaten in het Latijn uit de Institutie, en van enkele onderdelen in de noten, waarin ik met andere auteurs in discussic ben getreden De volledige tckst zal worden afgedrukt in de Congresreferate van het Calvijn-congres, Bloemfontein. 1992.

2 In dit artikel richt ik mu vooral op de leer van de praedestinatic bij Calvijn en Dordt $\mathrm{Er}$ zijn meer punten van overecnkomst Dic verder te nocmen en uit te werken, zou de omvang van dit artikel te buiten gaan. Ik heb gekozen voor een principe-vergelijking van Calvijns verkiezingsloer en dic van Dordt. Het is gewenst de volledige tekst van het referaat in de congresbundel te raadplegen

3

Voor dc editio princeps van Calvijns Insturutıo Christianae Religıonis, zie Simpson (1982:26-32) en de zeer recent verschenen vertaling van de hand van Van 't Spijker (1992) 
rakteristieker dan een 'wezenlijk punt'. Van 't Spijker citeert Stephens die stelt dat de praedestinatie "shapes the whole of Bucers' theology" (Van 't Spijker, 1976:87) ${ }^{4}$ en concludeert dat de praedestinatie voor beide reformatoren een centraal thema betreft (Van 't Spijker, 1985:33).

Datzelfde kan van Luthers theologie gezegd worden. Een vergelijking tussen beider praedestinatieleer is eveneens door Van 't Spijker gemaakt. Voor Luther geldt dat hij heel zijn leven heeft vastgehouden aan de dubbele praedestiatieleer. Zij hangt voor hem samen met de alwerkzaamheid van God en met de alleenwerkzaamheid van God. Wel waren de twijfels van Luther omtrent de praedestinatie de ergste. Hij vindt echter troost in de belofte (Van 't Spijker, 1983:156 e.v.). ${ }^{5}$ Die belofte rust in Christus. Christus moet elke dag weer de spiegel zijn waarin wij zien hoe lief God ons heeft (Van 't Spijker, 1985:33; zie ook Rost, 1966:71). Alleen in Hem wordt de duistere zijde van de verborgen God voor ons zichtbaar (Van 't Spijker, 1985:34) ${ }^{6}$

Calvijn mag wat de praedestinatie betreft een leerling van Luther heten: hij heeft diens gedachten vooral door de bemiddeling van Bucer leren kennen

Reeds in 1536 staat de praedestinatie in het kader van de ecclesiologie. De verkiezing is grond voor de zekerheid. De verkiezing wordt verbonden aan de roeping en de rechtvaardiging. $\mathrm{Zij}$ is altijd verkiezing binnen de gemeenschap van de kerk. Christus, de Here, wil de onze zijn. In Hem heeft de Vader van eeuwigheid verkoren hen die Hij de Zijnen wil noemen. Christus toe te behoren is het teken van de verkiezing. Wie met Christus niet tevreden is en ertoe neigt om nog hoger te klimmen, roept de toorn van God jegens zich wakker. Hij dringt binnen in de afgrond van Zijn Majesteit en wordt door de heerlijkheid Gods terneergeslagen. Het is belangrijk dit ecclesiologisch, wil men soteriologisch ${ }^{7}$ kader van de plaats van de verkiezing in de eerste uitgave van de Institutie vast te stellen; overigens dus in aansluiting bij Bucer en via hem bij Luther. Daarnaast is het van belang te wijzen op Christus als de grond van het heil, dat ons in de leer van

4 Voor teksten van Bucer over de pracdestinatic zie men De Kroon (1991:20-35), voorafgegaan door cen inleiding

5 Voor de aanvechtıngen van Luther, speciaal in verband met de praedestinatic, zie men ook Van Loewenich (1983:77-79); Lohse (19822:35-39); en vooral Brecht (19832'82-88)

6 Men zic Opera Selecta, ed Niesel $\left(1957^{2} 1,1,87,88\right)$ (te citeren als $O S$ ). We treffen deze passage aan in cap II De Fide, in par. 4, waar het artikel over de kerk uit het Apostolicum wordt besproken

7 We gebruken hier de term soleriologie, omdat het bij deze bespreking over de inhoud en de verwerkelijking van het heil gaat 
de verkiezing wordt verzekerd. Hier ligt eveneens een duidelijke overeenkomst tussen hem en Luther.

\section{De tweede en latere uitgaven van de Institutie}

In de tweede uitgave van de Institutie vindt er een verschuiving plaats. De opbouw van de Institume verandert: de praedestinatieleer wordt nu behandeld achter de soteriologie, samen met de voorzienigheid: hier is de invloed van Bucer duidehjk merkbaar (Wendel, 1968:119; Van 't Spijker, 1976:102-107).

Wat Calvijn betreft, is het belangrijk vast te stellen dat Bucers commentaar op de Romeinenbrief hem heeft beinvloed bij het schrijven ongeveer tegelijktijdig ${ }^{8}$ van zijn commentaar op Romeinen en zijn tweede uitgave van de Institutie. Zij zijn om zo te zeggen elkaars spiegelschrift. Verband en verschil tussen beide kan men met Van 't Spijker (1976:103) omschrijven als: in zijn commentaar biedt Calvijn de exegese, terwijl de Institutie vooral dogmatische verhelderingen wil geven. Men bedenke dat dit de reden is waarom Calvijn in boek III van zijn Instıtutte de leer voorop doet gaan (XXI) en dat hij pas in XXII spreekt over de bevestiging van deze leer door getuigenissen van de Schrift. Deze volgorde heeft niets te maken met het feit dat Calvijn van de ervaring zou uitgaan, om daama pas de Schrift aan te voeren als bevestiging (confirmatio) van de ervaring. Trouwens, ook in hoofdstuk XXI komen we verwijzingen naar de Schnft tegen, zoals in elk hoofdstuk van Calvijns Instmulte. Calvijn heeft tegelijkertijd gewerkt aan zijn commentaar op Romeinen en aan de tweede uitgave van de Institutie. Het verschil in doelstelling van beide publicaties brengt mee verschil in aanpak. Het tekent Calvijn, dat hij zelfs in de tweede uitgave van de Institurie het getuigenis van de Schrift niet achterwege laat, maar in een apart hoofdstuk een plaats geeft (Graafland, 1987:16). ${ }^{9}$

Behalve dit argument valt tegen deze kntiek in te brengen, dar Calvijn ook in zijn dogmatische uiteenzettingen steeds naar de Schrift verwijst. De Bijbel gaat ten aanzien van de praedestinatie niet pas open in XXII (Graafland, 1987:22). ${ }^{10}$

8 Zie Kamphuis $(1989: 24,25)$ en De Gref (1989 85 c v : 182) over de commentaar op Romeinen en over de tweede uitgave van de Institulte. met literatuurvermelding in noot 9 aldaar. Zic verder ook Parker (1971.53 c.v.)

9 Graafland verwijt Calvijn dat hij van de ervaring uitgaat. Hij zegt het her wel erg cru Calvijn zou inzetten bij de ervaring en pas via de Schrift tot de definitic van Gods ceunig besluit komen

10 Hij zegt dat de spanning tussen de menselijke crvaring als bron van kennis aangaande Gods verkiezing en het reformatorisch principe van het Sola Scriptura voor Calvijn in het geheel niet hecft bestaan. Graafland spruekt over een indruk dic zo bij hem overkomt 
We willen er nog op wijzen dat de voorzienigheid in de vierde uitgave van de Institutie van plaats wisselt. Die komt in 1559 in boek I (Calvijn, O.S., 3:187201). ${ }^{11}$ Dat is een belangrijk verschil tussen de tweede en de vierde uitgave van de Institutie. Deze verandering verandert echter niet de structuur van Calvijns verkiezingsleer.

Reeds in de tweede uitgave vinden we Calvijns praedestinatieleer in principe beschreven (Van 't Spijker, 1976:104). Wat daarna volgt, is hoogstens uitbreiding; maar geen verandering; in geen geval een verandering zoals die tussen de eerste en de tweede uitgave van de Institutie te constateren is.

We stellen vast dat de leer van de praedestinatie nu (de uitgave van 1559) het sluitstuk van de soteriologie is. Dit is Calvijn ten voeten uit - de praedestinatie als de verankering van het heil. In geen geval praedestinatie als een besluit van God buiten het heil om. Laten we dat nu reeds duidelijk vaststellen. "Haar functie is om het genadekarakter van het heil te funderen" (Graafland, 1987:6); aldus Graaflands conclusie reeds met betrekking tot de plaats van de verkiezing in de eerste uitgave van de Institutie. Deze karakterisering lijkt me voor de volgende uitgaven niet minder van toepassing.

Dat is te meer opmerkelijk omdat er in de opzet en doelstelling van de Institutie wel het een en ander is veranderd. Van catechismus als leerboek voor de gemeente krijgt ze nu met het oog op de studie van de theologie een meer systematisch-theologische vorm (Graafland, 1987:6). Juist dan moet het opvallen dat de verkiezing behandeld wordt aan het eind van het werk van de Heilige Geest, na de applicatio salutis (Graafland, 1987:6). ${ }^{12}$ Dat de praedestinatie nu met nadruk de afsluiting van de soteriologie wordt en blijft, is niet in tegenspraak met de eerste uitgave van de Institutie. Deze plaatsing is bedoeld als een versterking van de samenhang van de verkiezing met de soteriologie.

\section{De grondlijn in III, 21.}

We willen nu eerst enkele grondlijnen uit XXI releveren, die we bij het cursorisch lezen van dat hoofdstuk tegenkomen. We doen dat om de intonatie van Calvijns spreken over de praedestinatie op te vangen.

Calvijn spreekt erover dat het verbond des levens niet bij alle mensen wordt gepredikt; en dat bij wie het gepredikt wordt, niet bij allen hetzelfde plaatsvindt. In

11 Het is cap XVI van boek I

12 Graafland (1987:6) spreekt in dit verband van een zoekhouding bij Calvijn Het is o.i. cen zocken naar de meest verantwoorde bijbelse vormgeving van de leer. 
dit onderscheid openbaart zich de wonderbare hoogheid van Gods oordeel (Calvijn, O.S., 4, 368; III, 21, 1). ${ }^{13}$

Hij spreekt in dit verband over grote en moeilijke vraagstukken - ingewikkeld noemt hij ze. Hij voegt er direct aan toe dat juist in de duisternis, waarin velen terechtkomen, het nut van deze leer en ook haar zeer zoete vrucht aan de dag komen. Onze zaligheid vloeit voort uit de bron van Gods onverdiende barmhartigheid. Daarvan zullen we nooit duidelijk overtuigd zijn, als niet eerst Zijn eeuwige verkiezing ons bekend is geworden die Gods genade verheerlijkt. De zaligheid wordt aan de genadige verkiezing toegeschreven. En God maakt uit louter welbehagen zalig die Hij wil (Calvijn, O.S., 4, 369; III, 21, 1). Hiermee is het fundament van onze zaligheid in het geding. Met het oog op wat mensen met de verkiezing doen, spreekt Calvijn over nieuwsgierigheid, vermetelheid, lichtzinnigheid en brutaliteit.

De verborgenheid van Gods wil (hier genoemd in verband met de praedestinatie) heeft Hij ons in Zijn Woord geopenbaard. Hij heeft geopenbaard, zoveel als Hij voorzag dat in ons belang en tot ons nut zou zijn (Calvijn, O.S., 4, 370; III, 21,1).

In de volgende paragraaf gaat Calvijn dieper in op het Woord als de enige kenbron van Gods wil en Gods heil. Daarbuiten is duisternis. Dwaas is wie daarbuiten meent te kunnen gaan.

Wij moeten ons er niet voor schamen iets niet te weten in die zaak waarin onwetendheid getuigt van weten. We moeten ons van het onderzoek naar die kennis onthouden. In dit verband spreekt Calvijn over verderfelijkheid en overmoed (Calvijn, OS. , 4, 371; III, 21, 3). Zo verstaan we wat de context van zulke scherpe, negatieve kwalificaties is, namelijk het zich verdiepen in de verborgenheden van God, buiten het Woord (van Zijn genade) om.

De Schrift is de school van de Heilige Geest en evenals daarin niets overgeslagen is, dat nodig en nuttig is om geweten te worden, zo wordt er niets geleerd dan wat nuttig is te weten. We moeten de gelovigen niet afhouden van al wat in de Schrift over de praedestinatie wordt geleerd (Calvijn, O.S., 4, 372; IH, 21, 3).

En dan: "Dit zal de beste maat van de ingetogenheid zijn, indien wij niet alleen in het lezen altijd God als Leidsman volgen, maar ook, wanneer Hij ophoudt met onderwijzen, wij ophouden wijs te willen zijn" (Calvijn, O.S., 4, 372; III, 21, 3).

Het is ons niet geoorloofd in de verborgenheden Gods door te dringen (Calvijn, O.S., 4, 372; III, 21, 3). Hierin is een scherpe uitval naar hen die de stof der

13 We laten in dit artikel de Latijnse tekst weg Dic is wel te vinden in mijn bijdrage aan de congresbundel 
praedestinatie aangrijpen om te lasteren, te blaffen en te bespotten (Calvijn, O.S., 4,372 ; III, 21, 4).

Ik zou aan deze inzet de volgende conclusies willen verbinden:

* Calvijn gaat uit van wat er onder de mensen gebeurt, als het Woord tot hen komt of niet komt. Wie hier van ervaring wil spreken, doet dat op een bijzondere manier. Calvijn tracht namelijk te traceren de gang en de werking van het Woord, als Gods Woord en Gods daad. Het gaat om ervaring van wat God doet

* Calvijn voert de verschillen tussen de mensen terug op de praedestinatie. Hij beseft dat dit heel wat is, en dat men er een totaal verkeerde kant mee op kan. Calvijn toont zich ervan bewust te zijn met ontzagwekkende dingen bezig te zijn.

* Juist dan wijst hij op het Woord als verklaringsgrond en als kenbron van het heil. Het Woord spreekt over de praedestinatie. Die is niet alleen nuttig, maar ook vol zoetheid. Duidelijk is in dit alles dat de praedestinatie niet dient om te verschrikken, maar om God te aanbidden en te bejubelen.

* We kunnen haar alleen kennen, als we ons aan het Woord houden. Wie zich buiten het Woord begeeft of beweegt, is eigenwijs, opgeblazen en overmoedig. Hij zal nooit de rechte kennis van God krijgen.

* Hier is te spreken van een soteriologische toonzetting van de praedestinatie in het kader van de rechte Godskennis, die we alleen vanuit Zijn Woord verkrijgen.

\section{Calvijns definitie}

Dan volgt de bekende omschrijving:

De praedestinatie noemen wij het eeuwige besluit Gods, waardoor $\mathrm{Hij}$ bij Zichzelf heeft vastgesteld, wat $\mathrm{Hij}$ wilde, dat van een ieder mens zou worden. Want niet allen worden met gelijke conditie geschapen; maar voor sommigen wordt het eeuwige leven, voor anderen de eeuwige verdoemenis voorverordineerd. Daarom, alnaarmate ieder tot het ene of tot het andere doel geschapen is, zeggen wij dat hij tot het leven of tot de dood gepraedestineerd is (Calvijn, O.S., 4, 374; 1II, 21, 5). ${ }^{14}$

14 We citeren ook de vertaling van Van it Spijker (1987 172): "Praedestinatic nocmen wij het ecuwig besluit, waardoor $\mathrm{Hij}_{\mathrm{j}}$ bij zichzelf heeft vastgesteld, wat $\mathrm{H}_{\mathrm{ij}}$ wilde dat van icder mens zou worden. Want wij worden nict allen onder dezclfde voonwaarde geschapen. De een wordt voor het eeuwige leven, de ander voor de ceuwige verdoemenis voorverordineerd En daarom: gelijk iemand geschapen is voor het ene of voor het andere docl, zo zeggen wij, dat hij of voor het leven of voor de dood is voorbestemd " 
In deze zelfde paragraaf verwijst Calvijn ter adstructie van deze omschrijving (Calvijn spreekt over een bewijs) naar Abraham en de zijnen; en expressis verbis naar teksten over de verkiezing van Israël, waarin Gods liefde tot dat volk tot uitdrukking komt (Deut. 4:37; 7:7;10:14;23:5). Dan lezen we de uitdrukking "het onverdiende verbond en de onafgebroken weldaden Gods als vruchten van de verkiezing". Met verwijzing naar Jesaja 41:9 spreekt Calvijn over een onafgebroken voortgang van de uitnemende milddadigheid van $\mathrm{Zijn}$ vaderlijke goedertierenheid (Calvijn, O.S., 4, 375; III, 21, 7).

Israël is voor Calvijn een duidelijke illustratie van de viije verkiezing door Gods verborgen raad. Hij spreekt in dit verband over genadige verkiezing (Calvijn, O.S. , 4, 377). ${ }^{15}$

We concluderen dat Calvijns omschriving in 5 een supralapsarische toonzetting heeft. Tegelijk stellen we dat de toelichting met verwijzing naar Israël duidelijk maakt dat het om Gods liefde gaat. De kwalificatie "genadige" verkiezing is wezenlijk voor Calvijns leer van de verkiezing. Genade en vrije liefde zijn karakteristiek voor Calvijns visie op de verkiezing.

In het vervolg van 7 wordt op die grond verder ingegaan, terwijl hij dan zegt: opdat de verkiezing doeltreffend en waarlijk bestendig zij, is het nodig op te klimmen tot het Hoofd, in wie de hemelse Vader de uitverkorenen, met elkander verenigt en door een onlosmakelijke hand met zich verbonden heeft ${ }^{16}$.

Wij treffen hier in 7 een nadere ontvouwing aan van Calvijns visie op de uitverkiezing - een ontvouwing van wat in de eerst gegeven omschrijving ingevouwen lag. Deze omschrijving vormt een geheel met het voorafgaande hoofstuk. Vandaar dat Calvijn het soteriologisch karakter van zijn praedestinatieleer ook in de omschrijving als afsluiting van XXI, expressis verbis verwoordt.

De Schrift toont duidelijk aan dat God door een eeuwige en onveranderlijke raad eenmaal vastgesteld heeft, welke mensen $\mathrm{Hij}$ eenmaal tot zaligheid wilde aannemen, en welke aan de andere kant aan het verderf prijsgeven. Wij beweren dat deze raad, wat betreft de uitverkorenen, gegrond is in Zijn onverdiende barmhartigheid, zonder enig aanzien der menselijke waardigheid; en dat van hen, die Hij aan de verdoemenis overgeeft, door Zijn wel recht-

15 Hauck (1950:III, 21, 7) heeft sterk de cenheid van Calvijns pracdestinatieleer en heilszekerheid benadrukt, met ecn uitwerking naar het ethos

16 Calvijn, $O S ., 4,377, \cdots$. ut efficax et vere stabilis sit electio, necesse est ascendere ad caput in quo electos suos caelestis Pater inter se colligavit, et sibi insolubili nexu devmxit." Hauck (1950:Il1,21,7) heeft sterk de eenheid van Calvijns pracdestinatielecr en heilzckerheid benadrukt, met cen uitwerking naar het ethos. 
vaardig en onberispelijk, maar toch onbegrijpelijk oordeel de toegang tot het leven gesloten wordt. Verder stellen wij vast, dat bij de uitverkorenen de roeping een getuigenis is van hun verkiezing. Dat verder de rechtvaardigmaking een tweede teken is, waardoor zij hun geopenbaard wordt, totdat men komt tot de heerlijkheid, waarin haar vervulling gelegen is. En evenals de Here Zijn uitverkorenen tekent door de roeping en de rechtvaardigmaking, zo maakt Hij ook aan de verworpenen, door hen uit te sluiten van de kennis Zijns Naams of van de heiligmaking zijns Geestes, als door tekenen bekend, welk oordeel hun te wachten staat (Calvijn, O.S., 4, 378; III, 21, 7).

Deze omschrijving is een nadere ontvouwing van de eerste. Zij hoort daar wezenlijk bij, al kan men zich afvragen waarom Calvijn niet direct deze ontvouwing heeft gegeven. I $k$ zou hier niet van een tweetrapsraket willen spreken, wel van een voortgang van de gedachte, waarbij het eerste deel niet zonder het tweede gelezen mag worden. Er is een innerlijke verbondenheid en daarom een wezenlijke samenhang. Nogmaals zij gezegd, dat wij, geleerd door de ontsporingen bij de interpretatie van Calvijn, graag directer op het slot waren afgegaan, en niet een aanvankelijke omschrijving op tafel hadden gelegd. Dan voorkomt men radicaal het misverstand - want dat is het - dat in de eerste omschrijving alles is gezegd. Dat is namelijk niet gebeurd.

Als we de bevestiging van deze leer door de getuigenissen van de Schrift nader bekijken (III, 22) valt al direct op dat Christus centraal naar voren komt, als de zeer heldere spiegel der genadige verkiezing (Calvijn, O.S., 4, 380). ${ }^{17}$ Alle weldaden die God tot het geestelijke leven schenkt, "komen uit deze ene bron voort, dat God verkoren heeft, die Hij wilde, en voordat zij geboren waren, de genade, die $\mathrm{Hij}$ hen wilde waardig keuren, afzonderlijk voor hen heeft weggelegd" (Calvijn, O.S., 4, 381 e.v..; III, 22, 2).

In dit kader wordt in 2 benadrukt dat er in de verkorenen niets is dat hun de verkiezing waardig doet zijn. De verkiezing is te danken aan Gods barmhartigheid (Calvijn, O.S., 4, 382; III, 22, 2). Ook in paragraaf 6 en 7 neemt Christus een centrale plaats is. Juist daarom kan gezegd worden, dat er in de mensen niets is, dat hen geschikt doet zijn om verkoren te worden.

Eerlijkheidshalve moeten we zeggen dat Calvijn in XXIII spreekt over het feit dat Paulus de schuld der verderving werpt op hen die haar door hun eigen goeddunken over zich brengen. Daarmee verzacht Paulus volgens Calvijn de hardheid

17 Men zic voor het niet filosofische, maar religieuze (de goedheid van God) uitgangspunt van Calvijns pracdestinaticlecr Scheibe (1897:118-120) en Leith (1989:120-138, 111, 22, 1). Men zie ook de cvenwichtige beoordeling door Neuser (1988:255-256). Het is nict juist dat Neuser op blz. 256 zegt dat Calvijn in zijn preken geheel vocr de verwerping zwijgt. Men zie die over Jacob en Esau 
van de uitspraak dat God de vaten des toorns ten verderve heeft bereid. Toch moet de voorbereiding ten bederve overgebracht worden naar de verborgen raad van God (Calvijn, O.S., 395, III, 23, 1). Vervolgens wordt gezegd dat alles teruggaat op Gods wil. Er is niets groter en hoger dan Gods wil (Calvijn, O.S., 4, 396; III, 23, 2).

Men mag hieruit echter niet de conclusie trekken dat zij tot schuld zijn gepraedestineerd. In dit verband spreekt Calvijn in 4 over de straf der rampzaligheid (Calvijn, O.S., 4, 397; III, 23, 4).

Calvijn heeft het in 5, lijkt ons, zelf hier moeilijk mee. We kunnen hier vragen stellen die door ons niet beantwoord kunnen worden: "Beter is een onwetendheid dan een lichtvaardige kennis" (Calvijn, O.S. , 4, 399; III, 23, 5). En dan gaat Calvijn, open en eerlijk in op verkiezing en verwerping. Hij spreekt over het "huiveringwekkende besluit" (Calvijn, O.S., 4, 401; III, 23, 7). ${ }^{18}$

Laat ons daarom liever in de verdorven natuur van het menselijk geslacht de duidelijke oorzaak der verdoeming, die ons nader bekend is, aanschouwen, dan de verborgen en geheel en al onbegrijpelijke oorzaak in Gods praedestinatie onderzoeken (Calvijn, O.S., 4, 403; III, 23, 8). ${ }^{19}$

Als laatste punt citeren we uit 12 :

Indien de heiligheid des levens het doel is van de verkiezing, moet zij ons meer opwekken en aanzetten tot een vurige overdenking van die zaligheid dan dat ze dient tot een voorwendsel van traagheid (Calvijn, O.S., 4, 406; III, 23, 12).

Wij trekken uit het bovenstaande de voorlopige conclusies:

* Dat Calvijn in de praedestinatie Gods vrijmacht ziet. God is in die vrijmacht rechtvaardig. Niemand is hoger dan Hij.

* Hoewel wij supralapsarische uitdrukkingen bij Calvijn aantreffen (Van Genderen \& Velema, 1992:219) vult hij die steeds weer aan met het wijzen op

De Kroon (1968:136-155) spreckt over de bipolaire structuur van de praedestinatie Het is voor ons de vraag of die term, later door $\mathrm{H}$. Berkhof gemunt. hier op zijn plaats is Op blz. 154 stelt hij dat Calvijn met de leer der dubbele pracdestinatie allesbchalve blij is geweest Het lijkt ons beter te zeggen dat Calvijn soms moete hoeft met de hoogte en de diepte van dit lecrstuk Men zie in dit verband ook Wallace (1990:275 e.v)

Zie ook Bouwsma (1988:173): "The doctrine clearly made him uncomfortable" Men zie de kritische opmerking van Balke (1991:20, noot 41): "een te constructieve en toch niet geslaagde poging om de mens Ican Calvin nader te komen". Niettemin noemt Balke dit boek een omwenteling in de Calvinologie Niemand kan er mocr omhoen. 
Gods barmhartigheid als bron van behoud, en op de schuld van mensen als oorzaak van verloren gaan.

* Als Calvijn spreekt over de verborgenheid, dan werpt deze term geen schaduw over de openbaring van het heil in Christus. Die openbaring is duidelijk. Daarvan kunnen we zeker zijn. Wij moeten ons aan het Woord en binnen de grenzen van het Woord houden. Als wij doordenken, komen we voor vragen te staan, zegt Calvijn. Verborgenheid wil zeggen, dat God God is. Hij gaat ons mensen te boven. Verborgenheid wil niet zeggen, dat het licht van de openbaring verduisterd wordt. De duisternis treedt daar op. waar wij de grens van de openbaring overschrijden; waar wij er niet meer genoeg aan hebben dat de verkiezing soteriologisch bedoeld is.

De verkiezing geeft vastheid aan het heil. Wat wij daarbuiten en daarboven willen weten, voert ons in het duister. Wij zijn mens en niet God. Wie als mens God wil zijn of op Gods plaats wil staan, komt in het donker. Hij zondigt en alle zonde brengt duisternis mee, vervreemding van God.

Verborgenheid zegt eigenlijk twee dingen: God is God. Wie als God wil zijn, dat is wie met het Woord, het geopenbaarde heil niet tevreden is, die kiest voor het donker.

Vervolgens: De soteriologische toonzetting van de verkiezing impliceert een door eigen schuld veroorzaakte donkerheid. Deze treedt in, als een mens met het Woord niet tevreden is. De duisternis is niet ontologisch noch theologisch, maar alleen hamartiologisch gemotiveerd! Dit is het merkwaardige evenwicht in Calvijns praedestinatieleer. De kern van het misverstand omtrent de donkerheid waarover Calvijn spreekt, is voluit hamartiologisch. Wie het heil verwerpt, en ook de verkiezing als wortel van het heil, gaat de weg van de duisternis. De soteriologie heeft hier als donkere keerzij de hamartiologie, zoals de soteriologie ook Gods antwoord is op de hamartiologie.

\section{Calvijns preken}

Ik wijs er nu nog op dat in Calvijns preken voortdurend weer over de verkiezing wordt gesproken als over de diepte en de bron van het heil. De verkiezing wordt gekend in Christus. Van Bruggen heeft dat in zijn scriptie duidelijk naar voren gehaald. 20

Zie Van Bruggen (1991) - vooral de preck over Daniël 12:1-2, p 8-18; over Job 13:1-10, p. 14; over Galaten 3:7-9, p. 44; 2e preek over Efcziers 1:3-4, p. 47-56, met conclusies op p. 57, over Efezièrs 1:13-14, p. 66-67. 
In een preek over Daniël 12:1-2 wordt over de troost van de verkiezing gesproken en direct daarmee verbonden over de zekerheid van het geloof. Christus heet ook hier de spiegel van de verkiezing.

Het geloof is de kopie die God ons geeft van het origineel dat Hij in Zijn geheime Raad heeft gemaakt toen $\mathrm{Hij}$ ons heeft verkoren. De verkiezing mag niet verzwegen worden, omdat het Woord dat ook niet doet. De verkiezing komt voort uit Gods pure goedheid en uit $\mathrm{Zijn}$ onverdiende barmhartigheid, en dat voor mensen die van nature verloren zijn (C.O., 42, 290). ${ }^{21}$

Het zijn dezelfde klanken die we ook in de Institutie horen.

Ook in een preek over Job 13:1-10 voert Calvijn de verkiezing terug op Gods goedheid en barmhartigheid (C.O., 38, 616). In het bijzonder in de preken over Efeze 1:1-3 horen we de taal van de Institutie, ook in dit opzicht dat ingegaan wordt op de vraag of dit een harde leer is. Het theocentrisch gezichtspunt wordt benadrukt. Geloof is een vrucht van de uitverkiezing. De zekerheid is ermee gemoeid. De verkiezing vindt plaats in Christus en bedoelt de heiliging. Verkiezing en heiliging zijn onlosmakelijk met elkaar verbonden. In dit alles openbaart God Zijn soevereiniteit. De verbondsgedachte is bepalend voor de toon van Calvijns' preken over de verkiezing (C.O. 51, 259,69).

Christus is het register waarin de gelovigen zijn ingeschreven. Ook hier in de derde preek over Efeze 1:4-6 heet Christus de kopie. Christus staat ook hier centraal. Al deze elementen komen zo mogelijk versterkt terug in de vijfde preek over Efeze 1:13, 14 (C.O., 51, 275, 276).

Tenslotte de preken over Genesis 25-27, dertien in getal daterend uit 1560. Heel de geschiedenis van Jakob en Esau wordt behandeld onder het gezichtspunt van verkiezing en verwerping. Dit wordt gedaan in infralapsarische zin, uitgaande van de schuld van mensen en de genade die God aan Jakob betoont. Er worden aan verkiezing en verwerping allerlei praktische consequenties verbonden. We moeten wel zeggen dat niet in alle preken de praedestinatie expressis verbis aan de orde komt; bijna niet in de zeven preken over Genesis 26:6-10, noch in de negende over Genesis 26:23-25. In de tiende preek (Gen. 26:26-35) slechts in de marge. Zo ook in de elfde preek (Gen. 27:1-7).22

21 C O verwijst naar de in de litcratuurlijst genoemde Opera van Calvijn

22 Voor deze preken verwijzen we naar Van der Linde (1992). Ze zijn te vinden in C.O., 68, $17-198$ 
Uit de beknopte aanduiding van deze preken - breder weergegeven door Van Bruggen - blijkt dat Calvijn op de verkiezing en de verwerping teruggaat zonder dat hij hier een dogmatisch thema tot norm voor de uitleg maakt. Als men zegt dat deze preken meer aansluiten bij bepaalde passages uit Calvijns Institutie waarin het decreet centraal staat, dan wil ik dat niet ontkennen. Van der Linde schrijft in verband met deze preken:

Het Evangelie roept ons op, ons allen zonder onderscheid, om daar deel aan te nemen. Die roeping tot het heil, het weer heel worden, gaat in de preken ruim en breed uit met nadruk op allen. Want allen worden genodigd om naar de waterstromen te komen, om te drinken, alles staat klaar, wie maar wil neme het levenswater om niet ... En hoe milder en breder God nodigt, des te minder zijn wij dus te verontschuldigen. Nadrukkelijk zegt hij ons, dat God ons in die algemene nodiging niet bedriegt, wij kunnen er werkelijk op aan (Van der Linde, 1992:13).

Vandaar dat we hem in deze preken zijn gemeente zo klemmend horen verzekeren, dat Gods genadige verkiezing wel uit de eeuwigheid, uit de verborgenheid komt, maar ertoe bestemd is om in ons leven-in-de-tijd de bron van kracht en troost te zijn. Er kan niet over gespeculeerd worden, er kan enkel uit worden geleefd. Dat wordt volgens hem geleerd in Gods levensschool, waar bescheidenheid, vertrouwen en nederigheid tot het abc behoren en dat blijven tot het eind toe.

Het zal toch wel zaak zijn, dat de nieuwe eenheid, die Christus in onze gebrokenheid brengt (Efeze 1) tot haar volle recht blijft komen, ook en juist daar (Van der Linde, 1992:14).

Deze preken zijn ook Calvijns, met nadruk op barmhartigheid en soevereiniteit en zonder een systeem of schema te drijven. Dat we met de preken uit Efeziërs 1 in een wat andere sfeer verkeren, zal duidelijk zijn. De tekst en context van Genesis en Efeziërs verschillen nogal van elkaar. Het is in geen geval waar dat Calvijn in later jaren wel dogmatisch over de uitverkiezing heeft geschreven, maar haar in de prediking steeds minder ter sprake heeft gebracht. Ook aan het eind van zijn leven komt de verkiezing ter sprake (Graafland, 1987:20 e.v.). ${ }^{23}$

\section{Verkiezing in Christus}

Toch zou ik nog op twee punten uit Calvijns verkiezingsleer wat nadruk willen leggen. Het gaat met name om de nadruk op de verkiezing in Christus. Het is na het voorgaande geen nieuw gegeven. Ik sluit me hierin graag positief aan bij

Hij meent dat er bij de oudere Calvijn een vervreemding optreedt tussen een orthodoxe theologiebeoefening en de verkondiging met betrekking tot de leer der verkiezing. 
Graafland, die erop wijst dat het christologische gehalte van de verkiezingsleer bij Calvijn een zwaar accent krijgt (Graafland, 1987:35). Wij kunnen de verkiezing alleen leren kennen in Christus, die immers "een zeer heldere spiegel der genadige verkiezing" wordt genoemd (Calvijn, Institutle. III, 24, 17, O.S. 4, 380). De Heilige Geest wordt de realisator en operator van de verkiezing genoemd doordat Hij de zondaar roept en doet delen in de rechtvaardiging. Roeping en rechtvaardiging - we zagen het hierboven al - zijn tekenen van de verkiezing (Calvijn, 1II, 21, 7). De Geest laat ons immers in Christus en Zijn weldaden delen (Calvijn, III, I, 1).

Dit noem ik de pneumatologische setting van Calvijns christologisch gestructureerde verkiezingsleer.

\section{Over Gods beloften}

Vervolgens benadruk ik dat Calvijns prediking prediking is van Gods beloften.

In III, 24,17 , vinden wij deze uitspraak ook in een discussie over de vraag naar de betrouwbaarheid van Gods beloften. Als Gods beloften gepredikt worden, bevestigen ze dan dat Hij datgene wil wat strijdt tegen zijn onschendbaar besluit? Met andere woorden: worden de beloften niet verlamd, leeggemaakt en in feite onbetrouwbaar gemaakt door het besluit van de verkiezing?

Dat is geenszins zo, want hoewel de beloften der zaligheid algemeen zijn, strijden ze toch in niets tegen de praedestinatie der verworpenen mits wij slechts onze geest richten op hun uitwerking. Wij weten dat de beloften eerst dan voor ons werkdadig zijn, wanneer wij ze door het geloof aannemen; maar wanneer daarentegen het geloof verijdeld is, is tevens ook de belofte teniet gedaan (Calvijn, III, 24, 17. O.S., 4, 429 e.v.)

Calvijn spreekt meermalen over de algemeenheid van de beloften (Institufie, III, 22,$10 ;$ O.S. 4,390 e.v.). ${ }^{24}$

Niet allen nemen de beloften aan. Niet allen verkrijgen het beloofde goed. Calvijn spreekt over de verschillende uitwerking aposteriori. Niet vooraf spreekt hij over het verschil, maar achteraf. Hij spreekt in dit verband wel over een inwendige roeping, die alleen krachtig is in de uitverkorenen (Institutie III, 24; O.S., 4, 411). De gave van het geloof is bijzonder $(C . O ., 9,67)$.

24 Calvijn spreckt in III, 4,14, OS, 4, 101, over promissiones universales, (24, 17, O.S.) promissiones generales $(4,429)$. Vergelijk de homilic op I Sam 2:25-30 (C. O, 29, 339350 , vooral 342). God richt Zich tot alien en nodigt zonder onderscheid (Jes. 42:6; C.O., 37, 64). Iedere hoorder wordt in het bijzonder aangespoord de belofte op zichzelf toe te passen en aan te nemen (Ps 125: 1; C.O. 32, 314, Ps 119:76: C.O., 32, 295.) 
God belooft de zaligheid in de weg van bekering. De zaligheid wordt niet zonder meer beloofd. Nodig voor het ontvangen van het beloofde goed is bekering en geloof (vgl. Congregration, C.O., 8, 113, 114).

De kemvraag is natuurlijk of de inhoud van de belofte gerelateerd is aan de praedestinatie. Wordt aan verkorenen een belofte gedaan, die van inhoud anders is dan die aan de niet-verkorenen, ofwel, zijn de beloften eigenlijk niet voor de laatsten?25

Het valt niet te ontkennen dat Calvijn het geloof de weg noemt om het beloofde te ontvangen. Dat is punt een. Het valt evenmin te ontkennen dat Calvijn geloof en verkiezing met elkaar in verband brengt.

Wat moet nu de conclusie zijn? Dat is de cruciale vraag. Naar onze gedachte deze, dat de verkiezing niet de inhoud van de belofte beheerst

Pas achteraf (aposteriori) komt de verkiezing aan de orde. In het aannemen van Gods beloften realiseert zich het verkiezende handelen van God. Dat zeker. Deze conclusie achteraf is echter geen bepaling of beperking vooraf. Dat is het beslissende punt. (Zie Van Campen, 1988 (66-67, met noot 35 en 37); Van 't Spijker, 1987b:158). Calvijn wijst steeds weer op het Woord. God wil dat wij tevreden zijn met de belofte (Institutie, 1II, 24, 5; O.S., 4, 416). Wij moeten niet elders te weten komen of Hij ons zal verhoren (Institutie, III, 24, 5; O.S., 4, 416, alwaar ook staat: in Christus hebben we een spiegel ontvangen). Vandaar ook, we herhalen het, dat we bij de roeping moeten beginnen en eindigen (Institutie, III, 24,$4 ; O . S ., 4,415){ }^{26}$

Hier moeten we ook erop wijzen dat de beloften alleen werkdadig zijn, als ze door het geloof worden aangenomen (Institutie, III, 24, 17; O.S., 4, 417). Kamphuis en anderen (1989:39 en noot 54 op blz. 62) herinneren er terecht aan dat hier het woord efficax wordt gebruikt. Dat betekent namelijk niet geldig, maar effectief, effect sorterend!

25 Zie voor een vergelijkbare problecmstelling in verband met uitwendige en inwendige roeping (Van Genderen \& Velema, 1992:528-532). Voor de samenhang van rocping en verkiczing zic men Krusche (1957:233-255).

26 Onze visie wordt breed beargumenteerd door het in noot 80 gecitcerde bock van $M$ van Campen. Dit is dezelfde visie op de beloften als welke we tegenkomen bij Hyperius. Zic over hem Van 't Spijker (1991:291-304, vooral 303 c.v.) 
Dat er geen relatie bestaat tussen belofte en ongeloof 27 is in zoverre waar, dat de belofte juist om geloof vraagt. Het ongeloof verhindert de belofte werkzaam te zijn! Hiermee is niet gezegd dat de beloften alleen aan de uitverkorenen gepredikt mogen worden. Het zou in strijd zijn met tal van plaatsen in de Institutie en met Calvijns preken als men die conclusie wil trekken. Het gaat in het hierboven besprokene niet om het wezen, maar om de werking van de belofte. Als de belofte niet aan ongelovigen gepredikt zou mogen worden, moest men eerst een gelovige zijn alvorens iets aan de belofte te hebben. Het is juist door de prediking van de belofte dat men van ongelovig gelovig wordt. Er is een vrije en onvoorwaardelijke belofteprediking. ${ }^{28}$ We herinneren aan de uitspraak dat Gods beloften nooit door ons ongeloof en onze ondankbaarheid worden uitgeblust (Institutie, III, 2, 32; O.S., 4, 42).

We sluiten dit korte overzicht hienmee af, en gaan niet in op de kritiek van sommigen, o.a. Althaus, dat de reflectie over eigen subjectiviteit naast het vertrouwen komt. Daarmee zou de zekerheid op de reflexie worden gefundeerd. Van Campen heeft deze stelling weerlegd (1988:71). Beslissend is dat Calvijn ons ertoe roept rustig te steunen op de belofte (Institutie, III, 24, 7; O.S., 4, 4 I 8 ).

\section{De Dordtse Leerregels}

Wij gaan nu over naar de Dordtse Leerregels. ${ }^{29}$

Eigenlijk is het merkwaardig dat we bij de interpretatie daarvan een problematiek tegenkomen die analoog is aan de praedestinatieleer van Calvijn.

Ook hier zullen we het geheel moeten wegen. We willen de intonatie van de Dordtse Leerregels opvangen. Laat ik op gelijke wijze te werk mogen gaan als bij Calvijn.

De inzet is infralapsarisch. De mens heeft zich met zijn zonde aan de vloek en de eeuwige dood schuldig gemaakt $(I, 1)$. Daania volgt de verwijzing naar Johannes 3:16 - het hart van het evangelie. Dan de verkondiging die God zendt $(1,3)$. Vervolgens de tweevoudige reactie van ongeloof en geloof $(I, 4)$, en de nadruk-

27 Graafland (1987:42) vermeldt dit als cen bezwaar tegen Calvijns conceptıc

28 We wijzen ook nog op het inhoudrijke bockje van Exalto (1978:40-56, vooral 43 e.v.) met oen besprekıng van Institufie, III, 24, cn ook andere gegevens bij Calvijn Voor belofteprediking zıc men Trimp (1989:52-80)

29 Zie hiervoor Dijk (1935 ${ }^{3}$ ) en vooral zijn dissertatie (1912) Men zie ook het eerste hoofdstuk "Historische schetslijn tot de herleving van de gereformeerde theologie in de $19 \mathrm{e}$ ceuw" in Yoo (1990) 
kelijke betuiging dat God niet de oorzaak of schuld van het ongeloof is. Anderzijds is het geloof gave van God $(I, 5)$.

Dan komt in I, 6 het eeuwige besluit ter sprake. Dit is een aposteriorische benadering die sprekend lijkt op die van Calvijn. Merkwaardigerwijs treffen we dan ook in de Dordtse Leerregels dezelfde voortgang aan als bij Calvijn. In 1, 6 komt Christus niet voor, maar wel de barmhartigheid van God. Men vergete niet dat in I, 2, 3, 4, enz. Christus is genoemd. De barmhartigheid van I, 6, kan niet anders zijn dan barmhartigheid in Christus. Dat wordt in I, 7, dan ook met nadruk gezegd. Wij kunnen het betreuren dat Christus niet reeds in I, 6, genoemd wordt. In geen geval mag men zeggen, gezien het voorafgaande, dat Christus pas in I, 7, aan de orde komt. De aposteriorische aanpak impliceert dat de christologie - evenals bij Calvijn - de toonzetting is van de praedestinatie!

Graafland (1987:141) spreekt in verband met 1,6 en 7, van één besluit. Hij onderscheidt daarbinnen tussen de verkiezing zelf én de realisering van de verkiezing. Wie echter onbevoordeeld I, 6 en 7, leest zal deze tweedeling, deze tweetrapsraket onmogelijk in 6 (eerste trap) en 7 (tweede trap) kunnen vinden. Het eerste deel van 7 herhaalt het besluit van de verkiezing met Christus in het middelpunt (Middelaar en Hoofd van alle uitverkorenen en een fundament der zaligheid, 7a) (Graafland, 1987:146). ${ }^{30}$ Dat is het wezen van de verkiezing. Zo men al meent over realisering van de verkiezing te kunnen spreken, dan komt zij aan de orde in het tweede gedeelte van 7, 'en opdat er', dus in $7 \mathrm{~b}$.

Hier gaat het over de verwerkelijking. Wij voor ons achten dit besluit zozeer een eenheid dat wij de realisering niet als een apart tweede deel van het besluit kunnen zien. Men bedenke dat deze door ons gegeven interpretatie ook daarom vereist is, omdat Christus anders tot middel van de genade wordt. Hij heet echter in 1, 7a, Middelaar, en in I, 7b, komen de middelen aan de orde. Het is ons niet mogelijk om over een willekeurige onderscheiding te spreken. Die komt in strijd met de letter van het artikel. Daar komt bij dat Graaflands interpretatie van het woordje ook in $7 \mathrm{~b}$. aanvechtbaar is, en dat om twee redenen. Ten onrechte stelt Graafland dat God dezen tot het heil in Christus heeft verkoren.

Kamphuis (1989:51) en Van Genderen (Van Genderen \& Velema, 1992:216, noot 27) hebben ondubbelzinnig aangetoond dat Graafland hier ten onrechte uitgaat van de tekst die in het Nederlands in 1983 is herschreven. Uit de oorspronkelijke tekst blijkt dat de Dordtse Leerregels - hoe zou het in aansluiting bij

30 Hij zegt dat als er alleen stond 'in Christus verkoren', dan zou dit aanleiding kunnen geven tot net pliatsicn van Christus in het hart van de verkiczing 
Efeze 1:4 ook anders kunnen - zeggen dat God verkoren heeft in Christus. ${ }^{31}$ De Latijnse formulering is niet dubbelzinnig, de nieuwe vertaling wel. Christus staat niet buiten het besluit der verkiezing, evenmin als dat in artikel 16 NGB het geval is. 32

Hiermee vervalt ook Graaflands redenering als zou in de hierop volgende zin: dewelke Hij God tot een Middelaar heeft gesteld, het woordje ook zou betekenen dat Christus nu pas, na de verkiezing, naar voren komt (Graafland, 1987:I45). In feite komt Graafland zo toch eigenlijk tot twee besluiten, ondanks het feit dat hij op blz. 143 over éen besluit spreekt.

Het in Christus verkoren wordt in I, 7b, duidelijk beleden. Daarom kan ook nooit zijn betekenen: vervolgens, hierna. Ook is hier duidelijk explicatief bedoeld. De verkiezing in Christus is als volgt! Nu krijgen we de bredere verwoording en toelichting.

Ten slotte $-1,7$, is blijkens de inzet: deze verkiezing, nadere, wezenlijke erbijbehorende omschrijving van I, 6. De christologische toonzetting is, blijkens de barmhartigheid in 1, 6, geimpliceerd. Hier treffen we een merkwaardige overeenkomst aan met Calvijns redeneertrant - zoals de tweede omschrijving (III, 2I, 7) ontvouwing is van de eerste (III, 2I, 5), zo I, 7, van I, 6 .

Wij zien dan ook geen enkele reden om Graafland (1987:148) bij te vallen, als hij stelt, dat de Dordtse Leerregels de verkiezing "wel zo christologisch mogelijk willen verstaan", maar dat uiteindelijk het zwaartepunt valt in een verkiezingsleer, waarin Christus (slechts) bij de uitvoering van de doelstelling der verkiezing wordt betrokken en niet bij de verkiezing zelf.

Afgedacht van het feit dat deze redenering met de letter van de Dordtse Leerregels in strijd komt, voegen we er nog twee bezwaren aan toe.

* Dan zouden de Dordtse Leerregels een verwrongen en daarmee verkeerde exegese van Efeze 1:4 hebben gegeven

* Vervolgens, wat kan het confessioneel (en leerstellig) betekenen dat men de verkiezing 'zoveel mogelijk christologisch' wil verstaan, maar het in feite

31 Bakhuizen van den Brink (1976:2, 232): ". ad salutem elegit in Christo, quem etıam ab aeterno Mediatorem et omnium Electorum Caput salutisque fundamentum constıtuit aque ita cos ipsi salvandos dare et ad cius communionem per Verbum en Spiritum suum efficaciter vocare en trahere, seu vera in ipsum fide donare iustificarc. sanctificare. et potenter ir Filii sui communione custoditos tandem glorificare decrevit. ad demonstrationem suae miscrıcordıac et laudem divitiarrum glorıosac duac gratiac"

32 Dit hecft ais consequentic dat ook volgens Graafland Christus in het hart van het besluit van de verkiezing staat 
niet doet. Dit verwijt is om zo te zeggen de keerzijde ervan dat men de Dordtse Leerregelds een verwrongen exegese van Efeze 1:4 toeschrijft. Het ene staat of valt met het ander.

Hier is met de handen tastbaar dat de uitdrukking 'zo christologisch mogelijk' alleen houdbaar is, als men met de letterlijke tekst van 'in Christus verkoren' aan het schuiven gaat. Dit laatste deden de Leerregels niet. Evenmin begingen ze de fout dat ze een niet-christologisch gestructureerde verkiezing toch nog wat christologisch wilde ombuigen of bijschaven - zonder dat dit in feite lukte.

Wij zien het besluit als een totaliteit; daarom is het ons onmogelijk met Graafland (1987:153) te spreken van het arminiaanse deel van het besluit.

Tenslotte willen we nog nagaan of we inderdaad van een grote spanning binnen de Dordtse Leerregels kunnen spreken. Graafland doet dat door 1 te interpreteren als een christologische inzet (Graafland, 1987:160), terwijl dan toch gesproken wordt van een materiële overheersing van de verkiezing over de voorafgaande christologische inzet (Graafland, 1987:160). Onze analyse heeft duidelijk gemaakt dat hier van een spanning net zo min sprake is als bij Calvijn. De christologische inzet leidt tot een christologisch bepaalde verkiezingsleer (Graafland, 1987:163).

Wij houden het erop dat we Calvijn en de Dordtse Leerregels mogen typeren als een aposteriorisch spreken over de verkiezing. Op dit punt buigen de Dordtse Leerregels terug naar Calvijn. Dat is belangrijker dan het door Graafland geconstateerde feit, dat er ook (N.B.) in hermeneutisch opzicht meer toenadering gezocht wordt in de richting van Calvijn (Graafland, 1987:163, noot 45). ${ }^{33}$

We herinneren nu nog aan de door Graafland in zijn boek Gereformeerden op zoek naar God voorgestelde herstructurering van de Dordtse Leerregels: Christus voorop, daarna de betekenis van het geloof, in III de volharding en in IV menselijke verantwoordelijkheid en goddelijke bewaring op elkaar betrokken en dan tenslotte in $V$ het besluit van de verkiezing (Graafland, 1990:214).

Naar ons oordeel is die herstructurering niet onmogelijk, maar ook niet strikt noodzakelijk, want de structuur van 1 is duidelijk aposteriorisch en daarmee heeft Graafland binnen I reeds verkregen wat hij door deze herstructurering alsnog wilde bereiken (Velema, 1990:176).

33 Vonr Calvijns hermeneutick zic men Torrance (1988) Verder Ganoczy \& Scheid (1983) 


\section{Nog twee vragen}

Er resten nog enkele vragen. We zullen die na het voorgaande niet uitvoerig beantwoorden. Dat is ook niet nodig, omdat anderen dat al eerder en met overtuigende argumentatie hebben gedaan. Volledigheidshalve noemen we ze.

Het gaat met name om de karakterisering van de Dordtse Leerregels (en ook van Calvijn). Moeten we ze voorstanders van supra of van infra noemen?

In het licht van al het voorgaande hebben we volle vrijmoedigheid om Calvijn en de Dordtse Leerregels ten principale als infra te karakteriseren. Er zijn uitdrukkingen die soms een andere kant uitwijzen, zegt Van Genderen (Van Genderen \& Velema, 1992:219). De grondtoon is ook volgens hem infralapsarisch. Op dit punt stem ik graag in met hem, met G.C. Berkouwer (1955:32le.v.) $)^{34}$ en met W.D. Jonker (1989:67) ${ }^{35}$ en vele anderen. Het aposteriorisch karakter van de inzet van de Dordtse Leerregels geeft alle recht tot deze conclusie. Zo ook het feit dat steeds weer de barmhartigheid van God met verloren mensen wordt genoemd; eveneens de aanduiding de genadige verkiezing en de verkiezing in Christus.

Hiermee is tegelijk een ander aangelegen punt geraakt: dat is het feit dat verkiezing en verwerping niet op één lijn staan. De gelukkige uitdrukking non eodem modo verwoordt dat op een klassieke manier (Bakhuizen van den Brink, 1976 278). ${ }^{36}$ De infralapsarische toonzetting verhindert de gelijkstelling van verkiezing en verwerping. Ik zal dit nu niet breder beargumenteren. Men zie de vele auteurs waarnaar in het notenmateriaal wordt verwezen (Van Genderen \& Velema, 1992: 221-225).

Volledigheidshalve heb ik deze twee punten genoemd. Als afsluiting hiervan stel ik de vraag of we met Berkouwer (Berkouwer, 1955:216, 221, 222) ons niet tot de schuldcausaliteit moeten beperken, zonder van verwerping te spreken. Hij wil, als ik hem goed begrijp, daar niet boven uitgaan.

34 Berkouwer spreckt over grote sympathic voor het infra-moticf en over de infra-tendens in de confessies.

35 Jonker zegt dat de Lecrregels wel op bepaalde punten supralapsarisch zijn te interpreteren Toch wordt zo gesproken m de Leerregels dat ze evenals de HC en de NGB infralapsarisch verstaan mocten worden Heyns (1978:93) stelt dat de Leerregels sterk infralapsansch spreken. Hij zelf meent dat het bijbels niet aanvaardbaar is om eenzijdig voor cen van beide op te komen

36 Men lette crop dat het eodem modo van harte wordt verworpen Hicruit stamt de formulering non eodem modo Voor non eodem modo zie men ook Douma (1966:295302) 
Het wil ons voorkomen, dat men met deze constatering als eindpunt beneden de maat van de Dordtse Leerregels blijft. De Dordtse vaderen hebben in aansluiting bij de Gereformeerde confessie en Calvijn, meer willen zeggen. De vrijmacht van God hebben ze in verkiezing en verwerping willen eren, zonder ook maar op enige wijze God tot oorzaak van de zonde te maken.

Deze grondstelling van de Dordtse Leerregels doet mij ze vandaag nog van harte aanvaarden. $\mathrm{Zij}$ hebben zich tegelijkertijd naar vier kanten tegen misvatting en dwaling afgeschermd.

Ik noem ze:

* Gods soevereiniteit heft de menselijke verantwoordelijkheid en schuld, ook in het besluit, niet op.

* God handelt genadig en rechtvaardig. Bij God is geen willekeur. Zijn doen is vol van majesteit en barmhartigheid.

* De prediking van het evangelie wordt niet beperkt tot de uitverkorenen. A.C. de Jong (1954:171-176) heeft de term kerygmatische universaliteit gesmeed. De roeping gaat uit naar allen, tot wie God Zijn Woord zendt.

* Evenmin als de kring tot wie de belofte komt beperkt wordt, wordt hun inhoud beperkt. Voor ieder die het Woord hoort, is de belofte dat God hem/ haar genadig wil zijn. En deze belofte is volstrekt betrouwbaar.

\section{Samenvattende conclusies}

We willen nu in een aantal stellingen het betoog samenvatten en de conclusies trekken. ${ }^{37}$ Wat nu volgt, geldt op gelijke wijze voor Calvijn als voor de Dordtse Leerregels.

* De inzet is concreet en historisch. Het gaat over mensen, die gezondigd hebben en die gered moeten worden.

* De hoge worp is deze dat behouden worden en verloren gaan op Gods raad worden teruggevoerd. Er is een besluit van verkiezing en van verwerping Dat is het theologische gezichtspunt.

* Alle heil komt ons toe uit de verkiezing, die een verkiezing in Christus is. Dit is het christologische gezichtspunt.

* De grond van de genadige verkiezing is het welbehagen van God.

37 Deze conclusies sluiten aan bij die van Van Genderen, al vallen ze nict geheel samen met de door hem geformulecrde (Van Genderen \& Velema, 1992:212) 
* Hiermee is de zekerheid omtrent het heil gegeven en beleden. Het gaat in de leer van de verkiezing ten diepste om het fundament van onze heilszekerheid. Dat is het soteriologische gezichtspunt. Er is geen sprake van crisis, twijfel of wat dan ook, voorzover het God betreft. Als er crisis en twijfel is, ligt de oorzaak daarvan bij ons.

* De leer van de verkiezing staat centraal in ons belijden. Ze is fundament en bron van het heil. Ze bepaalt de leer omtrent God, omtrent de mens, omtrent de zonde, omtrent de Verlosser en de verlossing, omtrent de kerk en de genademiddelen en de toekomst (eschatologie). Dit is het confessioneel-dogmatisch gezichtspunt.

* Deze leer maakt mensen niet zorgeloos, maar vervult hen met eerbied, met vreze Gods en met vrede.

* $\quad \mathrm{Zij}$ maakt het gebruik van de genademiddelen tot een maximale verplichting. $7_{e}$ is daarmee een onvoorstelbare stimulans voor prediking, pastoraat en catechese, zowel binnen als buiten de kerk. Van deze middelen bedient Zich de Heilige Geest. Dit is het pneumatologische gezichtspunt.

* De verwerping staat geheel in de schaduw van de verkiezing. God voltrekt, krachtens zijn besluit, aan de verworpenen de dood, waarvoor zij in hun zondige eigenwaan hebben gekozen.

* Wij hebben in de leer van de verkiezing te doen met God, die ons begrip te boven gaat. Hem aanbidden wij in Zijn genade en wij prijzen Hem om de zekerheid die Zijn Woord ons biedt. Hem danken wij voor Christus, het fundament van onze zaligheid. Hem loven wij, omdat wij Hem mogen kennen en lieflebben. Datgene waarin wij Hem niet kunnen begrijpen, schokt ons niet in de zekerheid van het heil. Zijn verkiezing staat garant voor eeuwig behoud. Daarom danken wij Hem voor de genade van de verkiezing.

H.A. Oberman heeft gewezen op de context van Calvijns verkiezingsleer: de gemeenten onder het kruis die met ogen verduisterd door bloed en tranen niets zien van Gods almacht en trouw en tegen alle tekenen in vasthouden aan het ene Woord: Hij kent de Zijnen. Hij laat niet varen de werken die Zijn hand begon. Het is mij te contextueel om te zeggen dat buiten deze context om Calvijns verkiezingsleer niet alleen afschuwelijk is, maar ook goddeloos (Oberman, 1988:48 e.v.). Wel stem ik met zijn conclusie in dat deze verkiezingsleer binnen deze ervaringshorizon een kostbaar ervaringsgoed is. Het gaat inderdaad om de ervaring van wat we belijden, ook ten aanzien van de verkiezing.

\section{Bibliografie}

BALKE, W. 1991. Nieuwe perspectieven voor het kerkhistorisch onderzoek in middenEuropa Amsterdam : Rijksuniversiteit 
BAKHUIZEN VAN DEN BRINK, JN 1976 De Nederlandse Belijdenisgeschriften in authentieke teksten met inleidingen en tekstvergelijkingen Amsterdam : Ton Bolland.

BERKOUWER, G.C. 1955 De verkiezing Gods Kampen : Kok.

BOUWSMA, W J 1988. John Calvin A Sixteenth Century Portrait. New York - Oxford Oxford University Press.

BRECHT, M $1983^{2}$ Martin Luther Sein Weg zur Reformation. Stuttgart : Calwer

CALVIJN, J 1896 Opere Quae Supersunt Omnia. Brunsvigae - C.A. Schwetschke et Jilium

CALVIJN, J. 1952². Opera Selecta. Ed. G. Niesel München : Kaiser.

DE GREEF, W 1989 Johannes Calvijn Zijn werk en geschriften. Kampen : Kok

DE JONG, A.C. 1954. The Well-Meant Gospel Offer Franeker : Wever

DE KROON, M.J.J.P. 1968. De eer van God en het heil van de mens. Roermond : Romen

DE KROON, M 1991 Martin Bucer en Johannes Calvijn Zoetermeer : Boekencentrum

DIJK, K. 1912 De strijd over infra- en supralapsarisme in de Gereformeerde Kerken van Nederland. Kampen : Kok.

DIJK, K. 1935 3 . Om 't eeuwig welbehagen. De leer der praedestinatie. Delf : Meinema

DOUMA, J. 1966. Algemene genade Goes: Oosterbaan \& Le Cointre

EXALTO, K 1978 De roeping. Een reformatorische bezinning Amsterdam: Ton Bolland

GANOCZY, A \& SCHELD, St. 1983 Die Hermeneutik Calvins Wiesbaden : Steiner

GRAAFLAND, C 1987. Van Calvijn tot Barth Oorsprong en ontwikkeling van de leer der verkiezing in het Gereformeerd Protestantisme 's-Gravenhage : Boekencentrum

GRAAFLAND, C. 1990. Gereformeerden op zoek naar God Godsverduistering in het licht van de gereformeerde spintualiteit. Kampen : Kok.

HAUCK, W A 1950. Die Erwahlten Pradestination und Heilsgewiszheit nach Calvïn. Gütersloh : Berteismann.

HEYNS, J A. 1978. Dogmatiek. Pretoria : N G Kerkboekhandel.

JONKER, W.D 1989. Uit vrye guns alleen Oor uitverkiesing en verbond Pretoria : NG Kerkboekhandel.

KAMPHUIS, J. 1989. Met Calvijn in een impasse? Betekent de gereformeerde leer van de uitverkiezing en evangelieprediking een blokkade voor de prediking van het evangelie? Ermelo : Woord en Wereld

KRUSCHE, W. 1957. Das Wirken des Heiligen Geistes nach Calvin Gottingen : Vanderhoeck \& Ruprecht

LEITH, JOHN H. 1989. John Calvin's Doctrine of the Christian Life. Louisville, Kentucky : John Knox Press

LOHSE, B $1982^{2}$ Martin Luther Eine Einfuhrung in sein Leben und sein Werk München : Beck.

NEUSER, W H. 1988 Handbuch der Dogmengeschichte, 2. Gottingen : Vanderhoeck \& Ruprecht

NIESEL, W $1957^{2}$ Opera Selecta München : Kaiser Verlag.

OBERMAN, H A 1988 De erfenis van Calvijn. Grootheid en grenzen Kampen : Kok

PARKER, T.HL. 1971 Calvin's New Testament Commentaries London: Clark.

ROST, G 1966 Die Prädestinationsgedanke in der Theologie Martin Luthers Berlin Evangelische Verlagsanstalt

SCHEIBE, M 1897. Calvins Pradestinationslehre Halle Max Niemeyer

SIMPSON, HW 1982. Calvinus Reformator. His Theology, Church and Society. Potchefstroom : PU for CHE

TORRANCE, Th F 1988 The Hermeneutics of John Calvin. Edinburgh Scottish Academic Press 
TRIMP, C. 1989. Klank en weerklank. Door prediking tot geloofservaring Barneveld Vuurbaak.

VAN BRUGGEN, T 199l. Fundamentele prediking. Over de predestinatie in de prediking van Johannes Calvijn Utrecht : Rijsuniversiteit.

VAN CAMPEN, M. 1988 Leven uit Gods beloften Een centraal thema bij Johannes Calvijn. Kampen : De Groot

VAN DER LINDE, S. 1943. De leer van de Heilige Geest bij Calvijn Wageningen Veenman.

VAN DER LINDE, S. 1992 Prediking en verkiezing Dertien preken over de onverdiende verkiezing van Jakob en de verwerping van Ezau (1562), Johannes Calvijn Kampen De Groot.

VAN GENDEREN, J. \& VELEMA, WH. 19932. Beknopte gereformeerde dogmatiek. Kampen : Kok

VAN LOEWENICH, W 1983. Martin Luther. Der Mann und das Werk. München : List Verlag

VAN 'T SPIJKER, W. 1976. Pradestination bei Bucer und Calvin (In Calvinus Theologicus Neukirchen : Neukirchener Verlag. p 85-111.)

VAN 'T SPIJKER, W. 1983. Luther, belofte en ervaring. Goes : Oosterbaan \& Le Cointre

VAN 'T SPIJKER, W. 1985 Luther en Calvijn De invloed van Luther op Calvijn blijkens de Institutie. Kampen: Kok

VAN 'T SPIJKER, W 1987. Teksten uit de Instifutie van Johannes Calvijn. Delft : Meinema

VAN 'T SPIJKER, W 1991. Die Pradestionation bei Hyperius (In Neuser, W Calvijn, Erbe und Auftrag. Festschrif fur W. Neuser Herausg von W van 't Spijker. Kampen : Kok p. 303 e v.)

VAN 'SPIJKER, W. 1992 Institutie 1536 (vert.) Kampen : De Groot

VELEMA, WH 1990. Nieuw zicht op gereformeerde spiritualiteit Kampen: Kok

WALLACE, R.S 1990 Calvin, Geneva and the Reformation Grand Rapids : Baker.

WENDEL, F. 1968 Calvin Ursprung und Entwicklung seiner Theologie Neukirchen Neukirchener Verlag

YOO, H.M 1990 Raad en daad. Infra- en supralapsarisme in de Nederlandse gereformeerde theologie van de $19 \mathrm{e}$ en $20 \mathrm{e}$ eeuw. Kampen : Mondiss 
